\title{
Front Matter: Volume 10425
}

, "Front Matter: Volume 10425," Proc. SPIE 10425, Optics in Atmospheric Propagation and Adaptive Systems XX, 1042501 (12 January 2018); doi: $10.1117 / 12.2293152$

SPIE. Event: SPIE Remote Sensing, 2017, Warsaw, Poland 


\title{
Optics in Atmospheric Propagation and Adaptive Systems $X X$
}

\author{
Karin U. Stein \\ Szymon Gladysz \\ Editors
}

13-14 September 2017

Warsaw, Poland

Sponsored by

SPIE

Cooperating Organisations

Innovation Centre for Sensor and Imaging Systems (United Kingdom)

ADS Scotland (United Kingdom)

The Knowledge Transfer Network (United Kingdom)

Visit Scotland (United Kingdom)

European Regional Development Fund (Belgium)

Technology Scotland (United Kingdom)

European Association of Remote Sensing Companies (Belgium)

European Association of Remote Sensing Laboratories (Germany)

The British Association of Remote Sensing Companies (United Kingdom)

Remote Sensing \& Photogrammetry Society (United Kingdom)

Published by

SPIE

Volume 10425 
The papers in this volume were part of the technical conference cited on the cover and title page. Papers were selected and subject to review by the editors and conference program committee. Some conference presentations may not be available for publication. Additional papers and presentation recordings may be available online in the SPIE Digital Library at SPIEDigitalLibrary.org.

The papers reflect the work and thoughts of the authors and are published herein as submitted. The publisher is not responsible for the validity of the information or for any outcomes resulting from reliance thereon.

Please use the following format to cite material from these proceedings:

Author(s), "Title of Paper," in Optics in Atmospheric Propagation and Adaptive Systems XX, edited by Karin U. Stein, Szymon Gladysz, Proceedings of SPIE Vol. 10425 (SPIE, Bellingham, WA, 2017) Seven-digit Article CID Number.

ISSN: 0277-786X

ISSN: 1996-756X (electronic)

ISBN: 9781510613140

ISBN: 9781510613157 (electronic)

Published by

SPIE

P.O. Box 10, Bellingham, Washington 98227-0010 USA

Telephone +1 3606763290 (Pacific Time) · Fax +1 3606471445

SPIE.org

Copyright @ 2017 , Society of Photo-Optical Instrumentation Engineers.

Copying of material in this book for internal or personal use, or for the internal or personal use of specific clients, beyond the fair use provisions granted by the U.S. Copyright Law is authorized by SPIE subject to payment of copying fees. The Transactional Reporting Service base fee for this volume is $\$ 18.00$ per article (or portion thereof), which should be paid directly to the Copyright Clearance Center (CCC), 222 Rosewood Drive, Danvers, MA 01923. Payment may also be made electronically through CCC Online at copyright.com. Other copying for republication, resale, advertising or promotion, or any form of systematic or multiple reproduction of any material in this book is prohibited except with permission in writing from the publisher. The CCC fee code is 0277 $786 \times / 17 / \$ 18.00$.

Printed in the United States of America.

Publication of record for individual papers is online in the SPIE Digital Library.

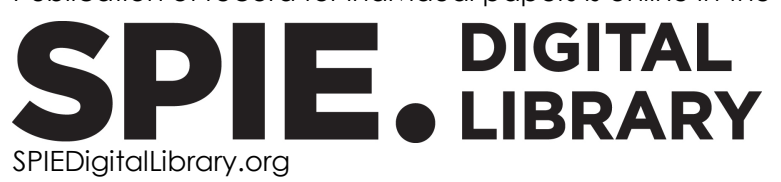

Paper Numbering: Proceedings of SPIE follow an e-First publication model. A unique citation identifier (CID) number is assigned to each article at the time of publication. Utilization of CIDs allows articles to be fully citable as soon as they are published online, and connects the same identifier to all online and print versions of the publication. SPIE uses a seven-digit CID article numbering system structured as follows:

- The first five digits correspond to the SPIE volume number.

- The last two digits indicate publication order within the volume using a Base 36 numbering system employing both numerals and letters. These two-number sets start with $00,01,02,03$, 04, 05, 06, 07, 08, 09, 0A, OB ... 0Z, followed by 10-1Z, 20-2Z, etc. The CID Number appears on each page of the manuscript. 


\section{Contents}

$\begin{aligned} \vee & \text { Authors } \\ \text { vii } & \text { Conference Committee }\end{aligned}$

\section{SESSION 1 CHARACTERIZATION OF THE ENVIRONMENT I}

1042502 Comparison of integrated optical turbulence over the sea in different coastal regions in the world [10425-1]

1042503 Temporally resolved refractive index structure parameter measurement [10425-5]

1042504 Meteorological measurements to characterize atmospheric turbulence variation [10425-3]

1042505 Characterizing the discoloration of EBT3 films in solar UV A+B measurement using red LED [10425-8]

\section{SESSION 2 CHARACTERIZATION OF THE ENVIRONMENT II}

1042506 Electro-optical propagation measurements during the MINOTAUROS experiment in the Cretan Sea [10425-2]

1042507 Characterization of underwater optical turbulence on the example of the Rayleigh-Benard water tank [10425-6]

1042509 Inhomogeneity of optical turbulence over False Bay (South Africa) [10425-4]

10425 OA Seasonal ionospheric scintillation analysis during increasing solar activity at mid-latitude [10425-9]

\section{SESSION $3 \quad$ FROM HERE TO THE STARS}

10425 OB Preliminary results from the Stereo-SCIDAR at the VLT Observatory: extraction of reference atmospheric turbulence profiles for E-ELT adaptive optics instrument performance simulations (Invited Paper) [10425-10]

10425 OD The turbulence study in the astronomical observatory in the North Caucasus [10425-12]

SESSION 4 ENVIRONMENTAL PARAMETERS

10425 OE Nightglow studies at Onera for night-vision applications (Invited Paper) [10425-13]

10425 OF Shortwave infrared for night vision applications at Fraunhofer IOSB [10425-14] 
$104250 G$ Experimental study on spectral absorbance in fog as a function of temperature, liquid water content, and particle size [10425-15]

$10425 \mathrm{OH}$ Aerosol optical properties inferred from in-situ and path-averaged measurements [10425-16]

$10425 \mathrm{Ol}$ The upper atmosphere layer height changes as a precursor of the Padang earthquake on 30 September 2009 [10425-17]

\section{SESSION $5 \quad$ ADAPTIVE OPTICS SYSTEMS}

10425 0J Dynamic adaptive control algorithm based on the realization of Kalman filter [10425-18]

10425 OK Holographic wavefront sensor, based on diffuse Fourier holography [10425-19]

\section{SESSION 6 BEAM PROPAGATION THROUGH TURBULENCE}

$10425 \mathrm{OL}$ Measurement of the spatial distribution of atmospheric turbulence with SCINDAR on a mosaic of urban surfaces (Best Student Paper) [10425-21]

$104250 \mathrm{M}$ Experimental studies of the correlation of wave-front aberrations of coherent radiation source and an extended luminous object [10425-22]

$10425 \mathrm{ON}$ Modelling of propagation and scintillation of a laser beam through atmospheric turbulence [10425-23]

$1042500 \quad$ Numerical studies of laser beam propagation with phase screen method using NonKolmogorov atmospheric turbulence [10425-24]

10425 OP Beam wander of focused electromagnetic multi-Gaussian Schell-model beams propagation in anisotropic turbulence [10425-25] 


\section{Authors}

Numbers in the index correspond to the last two digits of the seven-digit citation identifier (CID) article numbering system used in Proceedings of SPIE. The first five digits reflect the volume number. Base 36 numbering is employed for the last two digits and indicates the order of articles within the volume. Numbers start with 00, 01, 02, 03, 04, 05, 06, 07, 08, 09, OA, OB...0Z, followed by 10-12, 20-2Z, etc.

Adomeit, Uwe, OF

Agbaje, Ganiyu Ishola, OA

Ahmed, Wasiu Akande, OA, Ol

Barros, Rui, 07

Bellisario, Christophe, $\mathrm{OE}$

Botygina, N. N., OM

Chacon-Oelckers, Arlette, $\mathrm{OB}$

Cheng, Mingjian, OP

Cherkasov, Dmitri Y., ON

Cohard, J.-M., OL

Cohen, LeO H., OH

Conan, J.-M., OL

Derelle, Sophie, OE

Dérie, Frédéric J., OB

Deschamps, Joel, OE

Dokukina, Olga I., ON

Ednofri, Ednofri, OA, OI

Eisele, Christian, 02, 06

Emaleev, O. N., OM

Forsling, Robin, 03

Gladysz, Szymon, 07

Gorelaya, Alina, OK

Grossmann, Peter, $\mathrm{OH}$

Gunter, Willi, 09

Guo, Lixin, OP

Henriksson, Markus, 03

Henry, Didier, OE

Hietala, E., OG

Hou, Weilin, 07

Huang, Qingqing, OP

Irvine, M., OL

Jokela, T., OG

Kanaev, Andrey V., 07

Krieg, Jürgen, OF

Kurt, Hamza, 00

Kutila, M., OG

Lagouarde, J.-P., OL

Langlois, Stephane, $\mathrm{OE}$

Lavrinov, V. V., OJ

Lavrinova, L. N., OJ

Le Louarn, Miska, OB

$\mathrm{Li}$, Jiangting, $\mathrm{OP}$

Lukin, V. P., OD, OJ, OM

Marlia, Dessi, OA

Mäyrä, A., OG

Milli, Julien, OB

Mugnier, L. M., OL

Navarrete, Julio, $\mathrm{OB}$

Nguyen, K.-L., OL
Nikolaeva, Oxana A., ON

Nosov, E. V., OD

Nosov, V. V., OD

Omar, Ahmad Fairuz, 05

Orlov, Vyacheslav, OK

Osborn, James, OB

Osman, Ummi Shuhada, 05

Pyykönen, P., OG

Robert, C., OL

Sarazin, Marc S., OB

Seiffer, Dirk, 02

Shtemenko, Ludmila S., ON

Shugaev, Fedor V., ON

Simoneau, Pierre, $\mathrm{OE}$

Sprung, Detlev, 02, 09

Stein, Karin U., 02, 06, 09, $\mathrm{OH}$

Sucher, Erik, 02, 06

Suhareva, Natalia A., ON

Taczak, Thomas M., 04

Tan, Kok Chooi, 05

Tepfer, Kathleen, 04

Tiihonen, M., OG

Torgaev, A. V., OD

Ullwer, Carmen, 09

van Binsbergen, Sven A., $\mathrm{OH}$

van Eijk, Alexander M. J., 02, 09, 0H

Venediktov, Vladimir, OK

Wendelstein, Norbert, 06

Wilson, Rebekah F., 04

Wilson, Richard R. W., OB

WU, Falin, OA, OI

Yıldız, Fehmiye, 00

Zhao, Yan, OA, Ol 
Proc. of SPIE Vol. $104251042501-6$

Downloaded From: https://www.spiedigitallibrary.org/conference-proceedings-of-spie on 26 Apr 2023 Terms of Use: https://www.spiedigitallibrary.org/terms-of-use 


\title{
Conference Committee
}

\author{
Symposium Chair
}

Klaus Schäfer, (Retired) Karlsruhe Institute of Technology, Institute of Meteorology and Climate Research (Germany)

Symposium Co-chair

Christopher M. U. Neale, University of Nebraska-Lincoln

(United States), Daugherty Water for Food Institute (United States)

Conference Chairs

Karin U. Stein, Fraunhofer-Institut für Optronik, Systemtechnik und Bildauswertung (Germany)

Szymon Gladysz, Fraunhofer-Institut für Optronik, Systemtechnik und Bildauswertung (Germany)

Conference Programme Committee

Ivo Buske, Deutsches Zentrum für Luft- und Raumfahrt e.V. (Germany)

Sylvain Cheinet, Institut Franco-Allemand de Recherches de SaintLouis (France)

David C. Dayton, Applied Technology Associates (United States)

Denis Dion Jr., Defence Research and Development Canada, Valcartier (Canada)

Vladimir P. Lukin, V.E. Zuev Institute of Atmospheric Optics (Russian Federation)

Cheryl Matson, University of California, San Diego (United States)

Sergio R. Restaino, U.S. Naval Research Laboratory (United States)

Alexander M. J. van Eijk, TNO Defence, Security and Safety (Netherlands)

Arthur D. van Rheenen, Norwegian Defence Research Establishment (Norway)

Mikhail A. Vorontsov, University of Dayton (United States)

Oskar F. von der Lühe, Kiepenhever-Institut für Sonnenphysik (Germany)

Session Chairs

1 Characterization of the Environment I

Alexander M. J. van Eijk, TNO Defence, Security and Safety (Netherlands) 
2 Characterization of the Environment II

Karin U. Stein, Fraunhofer-Institut für Optronik, Systemtechnik und Bildauswertung (Germany)

3 From Here to the Stars

Szymon Gladysz, Fraunhofer-Institut für Optronik, Systemtechnik und Bildauswertung (Germany)

4 Environmental Parameters

Karin U. Stein, Fraunhofer-Institut für Optronik, Systemtechnik und Bildauswertung (Germany)

5 Adaptive Optics Systems

Oskar F. von der Lühe, Kiepenhever-Institut für Sonnenphysik (Germany)

6 Beam Propagation through Turbulence

Christian Eisele, Fraunhofer-Institut für Optronik, Systemtechnik und Bildauswertung (Germany) 